\title{
USPOREDBA TOČNOSTI PROCJENE STRUKTURNIH ELEMENATA SASTOJINA FOTOGRAMETRIJSKOM IZMJEROM AEROSNIMAKA RAZLIČITIH PROSTORNIH REZOLUCIJA
}

\author{
ACCURACY COMPARISON OF PHOTOGRAMMETRICALY \\ ESTIMATED FOREST STAND ATTRIBUTES ON AERIAL \\ IMAGES OF DIFFERENT SPATIAL RESOLUTION
}

\author{
Ivan BALENOVIĆ ${ }^{1}$, Ante SELETKOVIĆ ${ }^{2}$ Renata PERNAR²
}

\begin{abstract}
Sažetak
U radu je istražena mogućnost primjene digitalnih aerosnimaka visokih prostornih rezolucija za procjenu glavnih strukturnih elemenata sastojina (srednji sastojinski promjer i visina, broj stabala, temeljnica i volumen). Za dio gospodarske jedinice 'Donja Kupčina - Pisarovina' (14 odsjeka) na sistematskom uzorku ploha provedena je manualna (klasična/analogna) stereo fotogrametrijska izmjera na aerosnimkama GSD $30 \mathrm{~cm} \mathrm{i} 10 \mathrm{~cm}$ (GSD - eng. Ground Sample Distance). Svakom stablu na plohi određena (interpretirana) je vrsta drveća, izmjerena visina i delineirana krošnja, na temelju čega su procijenjeni glavni strukturni elementi sastojina. Kako bi se utvrdila točnost fotogrametrijski procijenjenih strukturnih elemenata sastojina provedena je usporedba s podacima terenske izmjere. Rezultati provedenog istraživanja potvrdili su velik potencijal primjene digitalnih aerosnimaka visokih prostornih rezolucija u stereomodelu pri inventuri šuma. Usporedbom rezultata fotogrametrijske izmjere na digitalnim aerosnimkama GSD $30 \mathrm{~cm}$ i GSD $10 \mathrm{~cm}$ s rezultatima terenske izmjere utvrđeno je da aerosnimke GSD $30 \mathrm{~cm}$ pružaju mogućnost procjene srednjih sastojinskih visina, sastojinske temeljnice i volumena s gotovo jednakom točnošću kao i aerosnimke GSD $10 \mathrm{~cm}$. Međutim, pogreške procijene srednjeg sastojinskog promjera i broja stabala bile su gotovo dvostruko veće na aerosnimkama GSD $30 \mathrm{~cm}$ nego na aerosnimkama GSD $10 \mathrm{~cm}$. Stoga se može zaključiti kako aerosnimke GSD $10 \mathrm{~cm}$ sveukupno daju bolje rezultate procjene strukturnih elemenata sastojina, jer prikazuje strukturu sastojine bliže stvarnoj.
\end{abstract}

KLJUČNE RIJEČI: inventura šuma, stereofotogrametrija, vizualna interepretacija, digitalne aerosnimke, digitalna fotogrametrijska stanica

\section{UVOD}

\section{INTRODUCTION}

Metode daljinskih istraživanja danas predstavljaju jedan od najvažnijih načina prikupljanja prostornih podataka u mnogim djelatnostima, a njihova primjena u šumarstvu ponaj- prije ima za cilj unaprijediti postojeće operativne metode prikupljanja podataka u inventuri šuma. Jedna od najstarijih, te ujedno i najčešće korištenih metoda daljinskih istraživanja u šumarstvu je vizualna (manualna) interpretacija, odnosno stereo fotogrametrijska izmjera aerosnimaka. Mogućnost procjene varijabli pojedinačnih stabala te strukturnih eleme-

${ }^{1}$ Dr. sc. Ivan Balenović, Hrvatski šumarski institut, Zavod za uređivanje šuma i šumarsku ekonomiku, Croatian Forest Research Institute, Division for Forest Management and Forestry Economics, Trnjanska cesta 35, HR-10000 Zagreb, Hrvatska, ivanb@sumins.hr

${ }^{2}$ Izv. prof. dr. sc. Ante Seletković, Prof. dr. sc. Renata Pernar, Sveučilište u Zagrebu, Šumarski fakultet, Zavod za izmjeru i uređivanje šuma, Univeristy of Zagreb,

Faculty of Forestry, Department of Forest Inventory and Management, Svetošimunska 25, HR-10002 Zagreb, Hrvatska 
nata šumskih sastojina fotogrametrijskom izmjerom na stereoparovima klasičnih analognih aerosnimaka primjenom analognih ili analitičkih stereoinstrumenata (tzv. analogna i analitička fotogrametrija) proučavali su brojni autori (npr. Ståhl 1992, Benko 1993, Næsset 1996, Kovats 1997, Anttila 1998, Eid i dr. 2004, Magnusson i Fransson 2005). Budući da su provedena istraživanja u pojedinim slučajevima (npr. jednodobne sastojine, kulture) pokazala zadovoljavajuće rezultate, aerosnimke su u većoj ili manjoj mjeri postale sastavni dio inventure šuma u pojedinim zemljama (npr. Finska, Švedska, Švicarska, Kanada) bilo na lokalnoj (uređajna inventura) ili regionalnoj odnosno nacionalnoj razini (nacionalna inventure šuma) (Næsset 2002, Magnusson i dr. 2007, Tuominen i dr. 2014, Ginzler i Hobi 2015). Međutim, u većini drugih zemalja, pa tako i Hrvatskoj, aerosnimke nisu našle širu praktičnu primjenu, pa se inventure šuma u tim slučajevima baziraju isključivo na klasičnoj terenskoj izmjeri. Razlozi tomu bili su višestruki: visoka cijena opreme i aerosnimaka, zahtijevan uredski rad koji iziskuju klasične fotogrametrijske metode, nedovoljno stručnih kadrova, ali i dobiveni rezultati koji često nisu udovoljavali svim potrebama prakse (Kušan 1996, Balenović i dr. 2010).

U međuvremenu, razvoj računalne tehnologije 80-tih i 90tih godina prošloga stoljeća potaknuo je snažan razvoj metoda i tehnika daljinskih istraživanja. Tako je i fotogrametrija, u posljednjih tridesetak godina, prošla razvojni put od analogne, preko analitičke do digitalne fotogrametrije tijekom kojega su analogne aerosnimke, te analogni i analitički stereoinstrumenti zamijenjeni digitalnim aerosnimkama te digitalnim fotogrametrijskim stanicama (Magnusson i dr. 2007, Linder 2009). Pri tomu su ključnu ulogu u razvoju iz analitičke $\mathrm{u}$ digitalnu fotogrametriju imali pojava digitalne fotogrametrijske stanice (DFS) krajem 1980-tih godina (Petrie 1997), te digitalnih aerofotogrametrijskih kamera 2000tih godina (Petrie i Walker 2007). Nakon toga slijedio je njihov kontinuirani razvoj, tako da današnje digitalne aerofotogrametrijske kamere omogućuju pridobivanje digitalnih aerosnimaka vrlo visokih prostornih i radiometrijskih rezolucija (Sandau 2010). Primjenom digitalnih aerosnimaka u kombinaciji s digitalnim fotogrametrijskom stanicom te raznim algoritmima za digitalnu obradu aerosnimaka, niz zahtjevnih fotogrametrijskih procesa (npr. aerotriangulacija, digitalno modeliranje terena, izrada digitalnog ortofota) je manje ili više automatiziran, a rukovanje aerosnimkama znatno olakšano.

Primjenom digitalnih aerosnimaka i DFS, informacije o pojedinačnim stablima i šumskim sastojinama mogu se dobiti analognim (manualnim) ili automatiziranim postupcima interpretacije (izmjere) (Gong i dr. 2002, Korpela 2004). Uslijed određenih nedostataka analognih metoda (veći angažman stručne radne snage - interpretatora, veći utrošak vremena, subjektivnost interpretatora), automatizirane metode u posljednje vrijeme zauzimaju znatno veće zanimanje istraživača. Rezultati provedenih istraživanja ukazuju na velik potencijal automatiziranih metoda pri procjeni strukturnih elemenata sastojina na razini plohe ili čitave sastojine (Ota i dr. 2015, White i dr. 2015, Yu i dr. 2015). Međutim, za točnu interpretaciju pojedinačnih stabala (npr. lokacija, vrsta drveća) automatizirane metode još uvijek ne mogu u potpunosti zamijeniti analogne, te je stoga njihova praktična primjena još uvijek upitna, posebno u mješovitim, gustim sastojinama (Smits i dr. 2012). Vizualnom interpretacijom odnosno klasičnom fotogrametrijskom izmjerom u stereomodelu, dio elemenata pojedinačnih stabala i šumskih sastojina moguće je izravno mjeriti, procjenjivati ili interpretirati na digitalnim aerosnimkama (vrsta drveća, broj stabala, visina stabala i sastojina, dimenzije krošnje, sklop), dok se drugi dio elemenata (prsni promjer, temeljnica, volumen) dobiva neizravno na temelju uspostavljenih odnosa (modela) između fotogrametrijski i terenski izmjerenih veličina.

U Hrvatskoj su u posljednjih nekoliko godina provedena određena istraživanja o mogućnostima primjene digitalnih aerosnimaka u inventuri šuma. Istraživana je njihova primjena u izlučivanju sastojina (Balenović i dr. 2012), za procjenu aritmetički srednjeg sastojinskog promjera (Balenović i dr. 2013) i aritmetički srednje sastojinske visine (Balenović i dr. 2015a, Seletković i dr. 2016), te za procjenu zdravstvenog stanja stabala (Kolići dr. 2015). U svim navedenim istraživanjima korištene su metode klasične fotogrametrijske izmjere i vizualne interpretacije digitalnih aerosnimaka na DFS, te su dobiveni rezultati ukazali na velik potencijal njihove praktične primjene.

Stoga ovaj rad predstavlja nastavak navedenih istraživanja, te ima za cilj ispitati mogućnost primjene digitalnih aerosnimaka visokih prostornih rezolucija u uređajnoj inventuri šuma. U tu svrhu provedena je klasična fotogrametrijska izmjera u stereomodelu na aerosnimkama prostorne rezolucije $30 \mathrm{~cm}$ i $10 \mathrm{~cm}$ na temelju kojih su procijenjeni glavni strukturni elementi sastojina (srednji sastojinski promjer i visina, broj stabala, temeljnica i volumen). Točnost fotogrametrijski procijenjenih strukturnih elemenata sastojina ispitana je usporedbom s podacima terenske izmjere. Dobiveni rezultati ukazali su na prednosti i nedostatke primjene aerosnimaka GSD $30 \mathrm{~cm}$ i aerosnimaka GSD $10 \mathrm{~cm}$ u uređajnoj inventuri šuma.

\section{MATERIJAL I METODE MATERIAL AND METHODS}

\section{Područje istraživanja - Study area}

Istraživanjem je obuhvaćen dio šumoposjedničkih šuma (14 odsjeka) gospodarske jedinice Donja Kupčina - Pisarovina (Uprava šuma Podružnica Karlovac) približne površine 480 ha (slika 1). G.J. se nalazi $25 \mathrm{~km}$ južno od Zagreba, u blizini mjesta Pisarovina. Nadmorska visina odabranog područja kreće se od 100 do 160 m, a nagibi su 

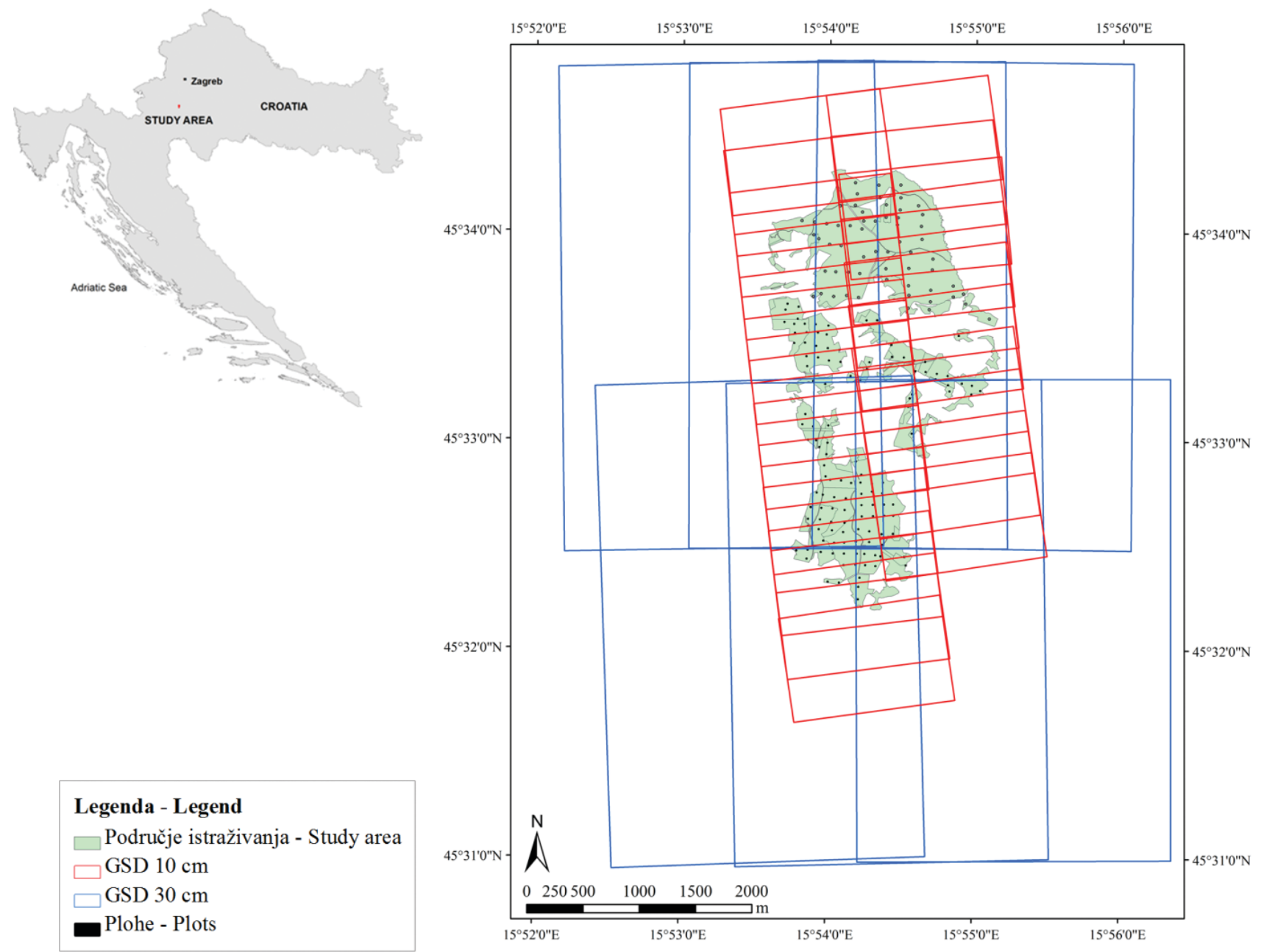

Slika 1. Položaj gospodarske jedinice Donja Kupčina - Pisarovina (lijevo, manja slika). Područje istraživanja s prostornim rasporedom primjernih ploha, te rasporedom (blokovima) aerosnimaka GSD $30 \mathrm{~cm}$ i GSD $10 \mathrm{~cm}$ (desno).

Figure 1 Geographic location of the management unit Donja Kupčina - Pisarovina (left). Study area with the spatial distribution of the forest inventory plots, and GSD $30 \mathrm{~cm}$ and GSD $10 \mathrm{~cm}$ image blocks (right).

u rasponu od $0^{\circ}$ do $30^{\circ}$. Glavne vrste drveća su: hrast kitnjak (Quercus petraea L.), obična bukva (Fagus sylvatica L.), obični grab (Carpinus betulus L.) i crna joha (Alnus glutinosa (L.) Gaertn). Od ostalih vrsta pridolaze divlja trešnja (Prunus avium L.), obični bagrem (Robinia pseudoacacia L.), trepetlijika (Populus tremula L.), obična breza (Betula pendula Roth) i dr. Nabrojane vrste tvore jednodobne sastojine uređajnog razreda hrasta kitnjaka, te raznodobne sastojine uređajnih razreda obične bukve i običnoga graba. Raznodobne sastojine uglavnom se sastoje od niza površinom manjih jednodobnih sastojina različitih razvojnih stadija. Iako se radi o šumoposjedničkim šumama kojima u prošlosti nije gospodareno prema svim pravilima šumarske struke, veći dio šuma izabranog područja dobre je kakvoće.

\section{Terenska izmjera - Field measurement}

Za potrebe istraživanja korišteni su terenski podaci prikupljeni u sklopu redovne inventure šuma g.j. Donja Kupčina
- Pisarovina. Terenski radovi provedeni su tijekom proljeća i ljeta 2009.g. prema tada važećem Pravilniku o uređivanju šuma (NN 111/06, 141/08), a odvijali su se u dvije faze. Tijekom prve faze, na području istraživanja postavljen je sistematski uzorak primjernih površina u obliku kružnih ploha na kojima je provedena izmjera prsnih promjera stabala. Ovisno o gustoći i starosti sastojina radijus ploha iznosio je 8 ili $12 \mathrm{~m}$. Sistematski uzorak postavljen je u obliku mreže točaka $100 \times 100 \mathrm{~m}, 100 \times 200 \mathrm{~m}$ ili $200 \times 100 \mathrm{~m}$, ovisno o veličini i obliku odsjeka te veličini ploha, kako bi se zadovoljio zadani intenzitet uzorkovanja od minimalno $2 \%$. U 14 odabranih odsjeka (267,29 ha) postavljene su 183 kružne plohe, što čini uzorkovanu površinu od 5,23 ha i intenzitet uzorkovanja od $2 \%$. Svim stablima na plohama iznad taksacijske granice od $10 \mathrm{~cm}$ izmjereni su prsni promjeri promjerkom od $100 \mathrm{~cm} \mathrm{~s}$ centimetarskom podjelom. Položaj primjernih ploha, tj. prostorne koordinate $(x, y)$ središta primjernih ploha snimljene su s MobileMapper 6 GPS prijemnikom (Magellan Navigation Inc, Santa Clara, 
Tablica 1. Osnovni strukturni elementi sastojina procijenjeni terenskom izmjerom: srednji sastojinski promjer $\left(\mathrm{DBH}_{\mathrm{g}}\right)$, Loreyeva srednja sastojinska visina $\left(H_{L}\right)$, te broj stabala $(N)$, temeljnica $(G)$ i volumen $(V)$ po jedinici površine (ha).

Table 1 Summary of the stand (subcompartment) level forest inventory data derived from field measurements $\left(\mathrm{DBH}_{\mathrm{g}}-\right.$ basal-area weighted mean dbh, $\mathrm{H}_{\mathrm{L}}$ - basal-area weighted mean height, Lorey's mean height, $\mathrm{N}$ - stand density, $\mathrm{G}$ - basal area, $\mathrm{V}$ - volume).

\begin{tabular}{|c|c|c|c|c|c|c|c|c|}
\hline $\begin{array}{l}\text { Uređajni razred } \\
\text { Management class }\end{array}$ & $\begin{array}{l}\text { Odsjek } \\
\text { Subcom- } \\
\text { partment }\end{array}$ & $\begin{array}{l}\text { Površina } \\
\text { Area (ha) }\end{array}$ & $\begin{array}{l}\text { Broj ploha } \\
\text { Number } \\
\text { of plots }\end{array}$ & $\begin{array}{l}\mathrm{DBH}_{\mathrm{g}} \\
(\mathrm{cm})\end{array}$ & $\begin{array}{l}\mathrm{H}_{\mathrm{L}} \\
(\mathrm{m})\end{array}$ & $\begin{array}{c}\mathrm{N} \\
\left(\text { stabala } \cdot \mathrm{ha}^{-1}\right. \\
\text { trees } \cdot \mathrm{ha}^{-1} \text { ) }\end{array}$ & $\begin{array}{c}\mathrm{G} \\
\left(\mathrm{m}^{2} \cdot \mathrm{ha}^{-1}\right)\end{array}$ & $\begin{array}{c}V \\
\left(m^{3} \cdot h a^{-1}\right)\end{array}$ \\
\hline \multirow[t]{4}{*}{ 0. petraea } & $18 a$ & 6,39 & 6 & 25,25 & 22,54 & 597 & 29,89 & 359,50 \\
\hline & $19 a$ & 2,70 & 3 & 22,81 & 21,68 & 647 & 26,43 & 300,55 \\
\hline & $20 a$ & 15,57 & 14 & 26,06 & 22,79 & 508 & 27,10 & 332,16 \\
\hline & $21 a$ & 9,91 & 9 & 27,09 & 23,10 & 420 & 24,22 & 303,71 \\
\hline \multirow[t]{6}{*}{ F. sylvatica } & $16 a$ & 44,07 & 22 & 20,84 & 20,88 & 634 & 21,61 & 230,38 \\
\hline & $17 a$ & 40,50 & 18 & 24,52 & 22,29 & 467 & 22,05 & 252,83 \\
\hline & $17 \mathrm{~b}$ & 28,71 & 15 & 19,62 & 20,32 & 807 & 24,39 & 250,52 \\
\hline & $18 b$ & 21,91 & 18 & 23,92 & 22,09 & 650 & 29,19 & 338,62 \\
\hline & $19 \mathrm{~b}$ & 7,11 & 5 & 22,22 & 21,45 & 667 & 25,84 & 295,78 \\
\hline & $20 c$ & 11,38 & 12 & 24,65 & 22,34 & 535 & 25,53 & 307,09 \\
\hline \multirow[t]{4}{*}{ C. betulus } & $17 c$ & 11,15 & 7 & 17,79 & 19,38 & 623 & 15,47 & 154,62 \\
\hline & $19 \mathrm{c}$ & 17,61 & 14 & 18,45 & 19,73 & 746 & 19,95 & 201,10 \\
\hline & $20 d$ & 20,46 & 17 & 20,46 & 20,71 & 761 & 25,02 & 267,53 \\
\hline & $21 b$ & 29,82 & 23 & 22,24 & 21,46 & 324 & 12,60 & 143,52 \\
\hline Ukupno / Total & & 267,29 & 183 & & & & & \\
\hline
\end{tabular}

California, USA) čija horizontalna točnost iznosi 2-5 m u idealnim uvjetima.

Visina svakog stabla kojemu je na primjernim plohama izmjeren prsni promjer izračunata je na temelju konstruiranih lokalnih visinskih krivulja izjednačenih Mihajlovljevom funkcijom (Michailloff 1943). Visinske krivulje konstruirane su za glavne vrste drveća (hrast kitnjak, obična bukva, obični grab, crna joha), ali su korištene i za izračun visina sporednih vrsta drveća. Visinska krivulja običnog graba korištena je za izračun visina sporednih vrsta drveća (obični bagrem, divlja trešnja) grupiranih u ostalu tvrdu bjelogoricu (OTB), dok je visinska krivulja crne johe korištena za izračun visina vrsta drveća (trepetljika, obična breza) grupiranih u ostalu meku bjelogoricu (OMB). Detaljniji opis korištenih visinskih krivulja (uzorak stabala, parametri izjednačenja, koeficijenti determinacije, korijen srednje kvadratne pogreške) prikazan je u radu Balenović i dr. (2015a). Na temelju izmjerenog prsnog promjera izračunata je temeljnica svakog stabla. Volumen krupnog drva iznad $7 \mathrm{~cm}$ izračunat je na temelju terenski izmjerenog prsnog promjera i visine procijenjene iz visinskih krivulja primjenom Schumacher-Hallove formule (Schumacher-Hall 1933) i parametara drvno-gromadnih tablica (Špiranec 1975, Cestar i Kovačić 1981, 1982, Bezak 2001). Za izračun volumena krupnog drva stabala grupiranih u OTB korišteni su parametri za obični grab (Špiranec 1975), dok su za vrste drveća gruprane u OMB korišteni parametri za trepetljiku (Cestar i Kovačić 1981).

$\mathrm{Na}$ temelju terenski uzorkovanih stabala, za svaki odsjek izračunati su osnovni strukturni elementi sastojina: srednji sastojinski promjer $\left(\mathrm{DBH}_{\mathrm{g}}\right)$, Loreyeva srednja sastojinska visina $\left(\mathrm{H}_{\mathrm{L}}\right)$, te broj stabala $(\mathrm{N})$, temeljnica $(\mathrm{G})$ i volumen (V) po jedinici površine (ha) (tablica 1). Strukturni elementi sastojina izračunati na temelju podataka terenske izmjere korišteni su kao referentne vrijednosti pri usporedbi s rezultatima fotogrametrijske izmjere.

\section{Fotogrametrijski materijal - Photogrammetric material}

Za fotogrametrijsku izmjeru korištene su digitalne infracrvene kolorne (ICK) stereo aerosnimke GSD $30 \mathrm{~cm}$ i GSD $10 \mathrm{~cm}$, te trodimenzionalni (3D) vektorski podaci na temelju kojih je izrađen digitalni model reljefa (DMR). Fotogrametrijski materijal snimila je i izradila tvrtka Geofoto d.o.o. Zagreb prema specifikacijama proizvoda Državne geodetske uprave.

Gotovo usporedo s terenskim mjerenjima, u srpnju 2009. god, obavljena su dva aerosnimanja (tzv. 'visoko' i 'nisko') područja istraživanja. Multispektralna aerofotogrametrijska snimanja podržana GPS/IMU tehnologijom provedena su 
digitalnom aerofotogrametrijskom kamerom velikog formata Microsoft UltraCamX (Microsoft, Vexcel Imaging $\mathrm{GmbH}, \mathrm{Graz}$, Austrija). Kamera je matričnog tipa, a sastoji od 13 CCD (eng. Charge Coupled Device) senzora. Pomoću 9 senzora prikupljaju se informacije u pankromatskom području, dok se preostala 4 senzora koriste za prikupljanje multispektralnih informacija iz plavog $(445-515 \mathrm{~nm})$, zelenog (510-590 nm), crvenog (600-680 nm) i blisko infracrvenog $(710-830 \mathrm{~nm})$ dijela spektra. Rezolucija kamere je 136 megapiksela, a žarišna duljina objektiva kamere pri snimanju iznosila je 100,5 mm. Detaljan opis tehničkih karakteristika kamere, kao i postupka obrade snimaka nakon leta, može se naći u radu Gruber i. dr. (2008).

'Visoko' aerosnimanje provedeno je pri prosječnoj visini leta zrakoplova od oko $4190 \mathrm{~m}$, što je rezultiralo prostornom rezolucijom aerosnimaka od $30 \mathrm{~cm}$. Područje istraživanja pokriveno je s ukupno 6 snimaka u 2 niza (slika 1). Prosječna visina leta 'niskog' aerosnimanja iznosila je oko $1400 \mathrm{~m}$, što je rezultiralo prostornom rezolucijom aerosnimaka od $10 \mathrm{~cm}$. Područje je snimljeno s ukupno 23 snimke u 2 niza (slika 1).

Pomoću GPS/IMU tehnologije korištene tijekom aerosnimanja, svakoj snimci zabilježena je precizna pozicija projekcijskog centra te parametri vanjske orijentacije. Prikupljeni „sirovi“ slikovni podaci su potom naknadno procesirani u postupcima radiometrijske i geometrijske korekcije. Spajanjem pankromatskih i multispektralnih aerosnimaka (eng. pan-sharpening) dobivene su ICK aerosnimke. Također, provedena je i aerotriangulacija aerosnimaka, koja je ispitana pomoću 15 kontrolnih točaka. Točnost aerotriangulacije, iskazana kroz korijen srednje kvadratne pogreške (RMSE, eng. Root Mean Square Error) navedena je u tablici 2. Također, u tablici su prikazane karakteristike oba aerosnimanja te karakteristike digitalnih aerosnimaka. Zajedno s digitalnim aerosnimkama dostavljeni su i parametri aerotriangulacije (unutarnje, relativne, vanjske, te parametri izjednačenja bloka aerosnimaka).

3D vektorski podaci za izradu DMR-a prikupljeni su stereo fotogrametrijskom izmjerom digitalnih aerosnimaka GSD $30 \mathrm{~cm}$. Vektorske podatke sačinjavale su lomne linije terena (prijelomnice), linije oblika, markantne točke terena i pravokutne mreže visinskih točaka međusobnog razmaka $25 \mathrm{~m}$.

\section{Fotogrametrijska izmjera - Photogrammetric measurement}

Fotogrametrijska izmjera provedena je na DFS korištenjem digitalnog fotogrametrijskog sustava PHOTOMOD 5.24 (Racurs Co., Moscow, Russia). Stereo vizualizacija i stereo izmjera omogućena je pomoću sustava za stereoskopko promatranje, kojega čine grafička kartica (NVIDIA Quadro

Tablica 2. Osnovni podaci o provedenim aerosnimanjima i aerosnimkama

Table 2 Acquisition parameters of aerial surveys and the characteristics of aerial images

\begin{tabular}{|c|c|c|}
\hline $\begin{array}{l}\text { Aerosnimanje } \\
\text { Aerial survey }\end{array}$ & $\begin{array}{l}\text { Visoko aerosnimanje } \\
\text { High aerial survey }\end{array}$ & $\begin{array}{l}\text { Nisko aerosnimanje } \\
\text { Low aerial survey }\end{array}$ \\
\hline $\begin{array}{l}\text { Datum } \\
\text { Date }\end{array}$ & 18.7.2009. & 22.7.2009. \\
\hline $\begin{array}{l}\text { Vrijeme (UTC+1) } \\
\text { Local time }(\text { UTC }+1)\end{array}$ & $11: 30-14: 00$ & $10: 00-12: 00$ \\
\hline $\begin{array}{l}\text { Vremenski uvjeti } \\
\text { Weather conditions }\end{array}$ & $\begin{array}{l}\text { vedro nebo, bez naoblake } \\
\text { clear sky, no wind }\end{array}$ & $\begin{array}{l}\text { vedro nebo, bez naoblake } \\
\text { clear sky, no wind }\end{array}$ \\
\hline $\begin{array}{l}\text { Kut upada sunčevih zraka }\left({ }^{\circ}\right) \\
\text { Sun elevation }\left({ }^{\circ}\right)\end{array}$ & $55-65$ & $55-65$ \\
\hline $\begin{array}{l}\text { Visina leta }(m) \\
\text { Flying height }(m)\end{array}$ & 4190 & 1400 \\
\hline $\begin{array}{l}\text { Preklop: Uzdužni / Poprečni (\%) } \\
\text { Overlap: Forward / Side (\%) }\end{array}$ & $60 / 30$ & $60 / 30$ \\
\hline $\begin{array}{l}\text { Broj aerosnimaka } \\
\text { Number of images }\end{array}$ & 6 & 21 \\
\hline GSD (cm) & 30 & 10 \\
\hline $\begin{array}{l}\text { Veličina aerosnimke (piksela) } \\
\text { Image size (pixels) }\end{array}$ & $14,430 \times 9,420$ & $14,430 \times 9,420$ \\
\hline $\begin{array}{l}\text { Veličina piksela }(\mu \mathrm{m}) \\
\text { Pixel size }(\mu \mathrm{m})\end{array}$ & 7,2 & 7,2 \\
\hline $\begin{array}{l}\text { Radiometrijska rezoucija (bit) } \\
\text { Radiometric resolution (bits) }\end{array}$ & 16 & 16 \\
\hline $\begin{array}{l}\text { Baza aerosnimanja }(\mathrm{m}) \\
\text { Base }(\mathrm{m})\end{array}$ & 1130,4 & 376,8 \\
\hline $\begin{array}{l}\text { Odnos baze snimanja i visine leta } \\
\text { Base-to-height ratio }\end{array}$ & 0,26 & 0,27 \\
\hline $\begin{array}{l}\text { Točnost orijentacije, RMSEx/y/z (m) } \\
\text { Orientation accuracy, RMSEx/y/z (m) }\end{array}$ & 0,090 / 0,097 / 0,038 & $0,121 / 0,088 / 0,020$ \\
\hline
\end{tabular}


K2000), stereo monitor (ACER Predator GN246HL) i stereo naočale (NVIDIA 3D Vision glasses kit). PHOTOMOD 5.24 je modularni sustav, tj. sastoji se od niza modula koji omogućuju izvođenje raznih fotogrametrijskih postupaka. Detaljan opis hardverskih i softverskih komponenti DFS-e dat je u radu Balenović i dr. (2015b).

Prije same fotogrametrijske izmjere provedena je priprema aerosnimaka (kreiranje stereo modela) i izrada DMR-a. U sklopu pripreme aerosnimaka, u modulu PHOTOMOD Core kreirani su projekti (definiranje projekcije, minimalne i maksimalne nadmorske visine područja) i formirani blokovi aerosnimaka (unos i pozicioniranje aerosnimaka). Zatim je slijedila orijentacija snimaka (aerotriangulacija) koja je provedena postupcima unutarnje, vanjske i relativne orijentacije, te izjednačenjem bloka aerosnimaka u PHOTOMOD AT modulu. Orijentacija aerosnimaka provedena je na temelju isporučenih parametara aerotriangulacije.

DMR je izrađen u PHOTOMOD DTM modulu. Na temelju 3D vektorskih podataka najprije je izrađena TIN mreža (nepravilna mreža trokuta, eng. triangulated irregular network) koja je potom interpolirana u rasterski DMR veličine piksela $1 \mathrm{~m} \times 1 \mathrm{~m}$.

Vizualna interpretacija i stereo fotogrametrijska izmjera provedena je u PHOTOMOD StereoDraw modulu, i to najprije u stereo modelu digitalnih aerosnimaka GSD $30 \mathrm{~cm}$, a potom i u stereo modelu aerosnimaka GSD $10 \mathrm{~cm}$.

Fotogrametrijske plohe postavljene su na aerosnimkama na temelju snimljenih prostornih koordinata $(x, y)$ središta primjernih ploha tijekom terenskog mjerenja pomoću GPS-a. Svakom stablu na plohi determinirana (interpretirana) je vrsta drveća, određen vrh stabla i delineirana krošnja. Vizualna interpretacija vrsta drveća provedena je na temelju raspoznavanja slikovnih značajki krošanja, točnije općeg izgleda (oblik krošnje, struktura i tekstura) i boje krošnje. Pritom su pomogla saznanja provedenih istraživanja o načinu preslikavanja pojedinih vrsta drveća na ICK aerosnimkama (Pernar 1994, 1997, Pernar i dr. 2007a, 2007b, 2008, itd.), te zapažanja tijekom terenskih radova u okviru ovog istraživanja. Sporedne vrste drveća (obični bagrem, divlja trešnja, trepetljika, obična breza) tijekom fotogrametrijske izmjere grupirane su u OTB i OMB. Vrh svakog stabla na plohi određen je polaganjem stereo markera na vrh krošnje, te je zabilježen 3D točkastim objektom s pripadajućim $x, y$, $z$ koordinatama. Na kraju je svakom stablu delineirana krošnja u obliku poligonskog objekta.

Dodatno prikupljanje potrebnih podataka provedeno je $\mathrm{u}$ QGIS-u (QGIS Development Team). Na temelju 3D točkastih objekata dobivene su nadmorske visine vrhova stabala, dok su nadmorske visine podnožja stabala dobivene iz ortogonalne projekcije vrhova stabala na tlo odnosno DMR. Fotogrametrijska visina svakog stabla na plohi izračunata je kao razlika fotogrametrijski određenih nadmorskih vi- sina vrha i podnožja stabla. Za izračun fotogrametrijskog prsnog promjera svakog stabla na plohi korišteni su regresijski modeli s promjerom krošnje i visinom stabla kao ulaznim (nezavisnim varijablama) (Balenović i dr. 2012.). U tu svrhu promjer krošnje svakog stabla izračunat je iz delineirane površine krošnje primjenom formule za površinu kruga. Regresijski modeli procjene prsnog promjera izrađeni su samo za glavne vrste drveća (h. kitnjak, o. bukva, o. grab, c. joha), a prsni promjeri stabala grupiranih u OTB izračunati su korištenjem modela za obični grab, te prsni promjeri stabala grupiranih u OMB korištenjem modela za crnu johu. Detaljan opis regresijskih modela procjene prsnih promjera dat je u radu Balenović i dr. (2012). Daljnji postupak izračuna elemenata pojedinačnih stabala (temeljnica, volumen) te strukturnih elemenata sastojine $\left(\mathrm{DBH}_{\mathrm{g}}\right.$, $\mathrm{H}_{\mathrm{L}}, \mathrm{N}, \mathrm{G}, \mathrm{V}$ ) bio je istovjetan izračunu terenskih podataka

\section{Analiza podataka - Data analysis}

Za ocjenu točnosti fotogrametrijske izmjere strukturnih elemenata sastojina na aerosnimkama GSD $10 \mathrm{~cm}$ i GSD 30 $\mathrm{cm}$, za svaki odsjek izračunata su odstupanja (D, prema eng. differences) fotogrametrijski procijenjenih od terenski procijenjenih vrijednosti strukturnih elemenata sastojina. Također, kao mjere odstupanja fotogrametrijski procijenjenih strukturnih elemenata sastojina u odnosu na terenski procijenjene za cijelo područje istraživanja izračunate su: srednje odstupanje (MD, prema eng. mean difference), i korijen srednje kvadratne pogreške (RMSE, prema eng. root mean square error). Sve mjere odstupanja iskazane su u mjernim jedinicama promatrane varijable, te u postotnom iznosu od referentne terenske vrijednosti prema formulama:

$$
\begin{gathered}
D=P_{i}-F_{i} \\
D_{\%}=\frac{\left(P_{i}-F_{i}\right)}{F_{i}} \times 100 \\
M D=\frac{\sum_{i=1}^{n}\left(P_{i}-F_{i}\right)}{n} \\
M D_{\%}=\frac{M D}{\bar{F}_{i}} \times 100 \\
R M S E=\sqrt{\frac{\sum_{i=1}^{n}\left(P_{i}-F_{i}\right)^{2}}{n}} \\
R M S E_{\%}=\frac{R M S E}{\bar{F}_{i}} \times 100
\end{gathered}
$$

gdje je n broj odsjeka, $P_{i}$ je fotogrametrijski procijenjena vrijednost promatrane varijable za odsjek $i, F_{i}$ je terenski 
Tablica 3. Odstupanja $\left(D, D_{\%}, M D, M_{\%}, R M S E, R S_{\%}\right)$ strukturnih elemenata sastojina $\left(\mathrm{DBH}_{\mathrm{g}}\right.$ - srednji sastojinski promjer, $\mathrm{H}_{\mathrm{L}}$ - Loreyeva srednja sastojinska visina, $\mathrm{N}$ - broj stabala, $\mathrm{G}$ - temeljnica, $\mathrm{V}$ - volumen) procijenjenih fotogrametrijskom izmjerom na aerosnimkama GSD 10 i GSD $30 \mathrm{~cm}$ u odnosu na referentne terenske vrijednosti.

Table 3 Stand level accuracy $\left(\mathrm{D}, \mathrm{D}_{\%}, \mathrm{MD}, \mathrm{MD}_{\%}, \mathrm{RMSE}, \mathrm{RMSE} \mathrm{E}_{\%}\right)$ for basal-area weighted mean dbh $\left(\mathrm{DBH}_{\mathrm{g}}\right)$, Lorey's mean height $\left(\mathrm{H}_{\mathrm{L}}\right)$, stand density $(\mathrm{N})$, basal area (G) and volume (V) estimated by photogrammetric measurement of GSD $30 \mathrm{~cm}$ and GSD $10 \mathrm{~cm}$ aerial images.

\begin{tabular}{|c|c|c|c|c|c|c|c|}
\hline $\begin{array}{l}\text { Varijabla } \\
\text { Variable }\end{array}$ & $\begin{array}{c}\text { Aerosnimke } \\
\text { Aerial images (GSD) }\end{array}$ & $\begin{array}{c}\text { D } \\
\text { raspon - range }\end{array}$ & $\begin{array}{c}\mathrm{D}_{\%} \\
\text { raspon - range }\end{array}$ & MD & $\mathrm{MD}_{\%}$ & RMSE & RMSE $_{\%}$ \\
\hline \multirow[t]{2}{*}{$\mathrm{DBH}_{\mathrm{g}}$} & 30 & $0,69-3,64$ & $3,03-16,49$ & 2,01 & 8,90 & 2,14 & 9,46 \\
\hline & 10 & $0,29-2,16$ & $1,14-9,45$ & 0,99 & 4,40 & 1,11 & 4,94 \\
\hline \multirow[t]{2}{*}{$\mathrm{H}_{\mathrm{L}}$} & 30 & $(-2,80)-0,67$ & $(-13,58)-2,82$ & $-0,67$ & $-3,01$ & 1,20 & 5,36 \\
\hline & 10 & $(-2,64)-0,88$ & $(-12,79)-3,70$ & $-0,61$ & $-2,73$ & 1,13 & 5,03 \\
\hline \multirow[t]{2}{*}{ N } & 30 & $(-152)-(-33)$ & $(-24,37)-(-5,13)$ & $-89,95$ & $-15,02$ & 95,24 & 15,90 \\
\hline & 10 & $(-69)-(-17)$ & $(-10,64)-(-2,56)$ & $-44,27$ & $-7,39$ & 46,19 & 7,71 \\
\hline \multirow[t]{2}{*}{ G } & 30 & $(-1,45)-2,64$ & $(-4,97)-10,21$ & 0,09 & 0,40 & 1,16 & 4,93 \\
\hline & 10 & $(-1,86)-2,58$ & $(-6,23)-12,94$ & 0,12 & 0,53 & 1,21 & 5,13 \\
\hline \multirow[t]{2}{*}{ V } & 30 & $(-25,54)-24,18$ & $(-10,20)-8,17$ & $-6,85$ & $-2,56$ & 13,45 & 5,04 \\
\hline & 10 & $(-19,84)-6,56$ & $(-7,01)-2,22$ & $-6,68$ & $-2,50$ & 9,75 & 3,65 \\
\hline
\end{tabular}
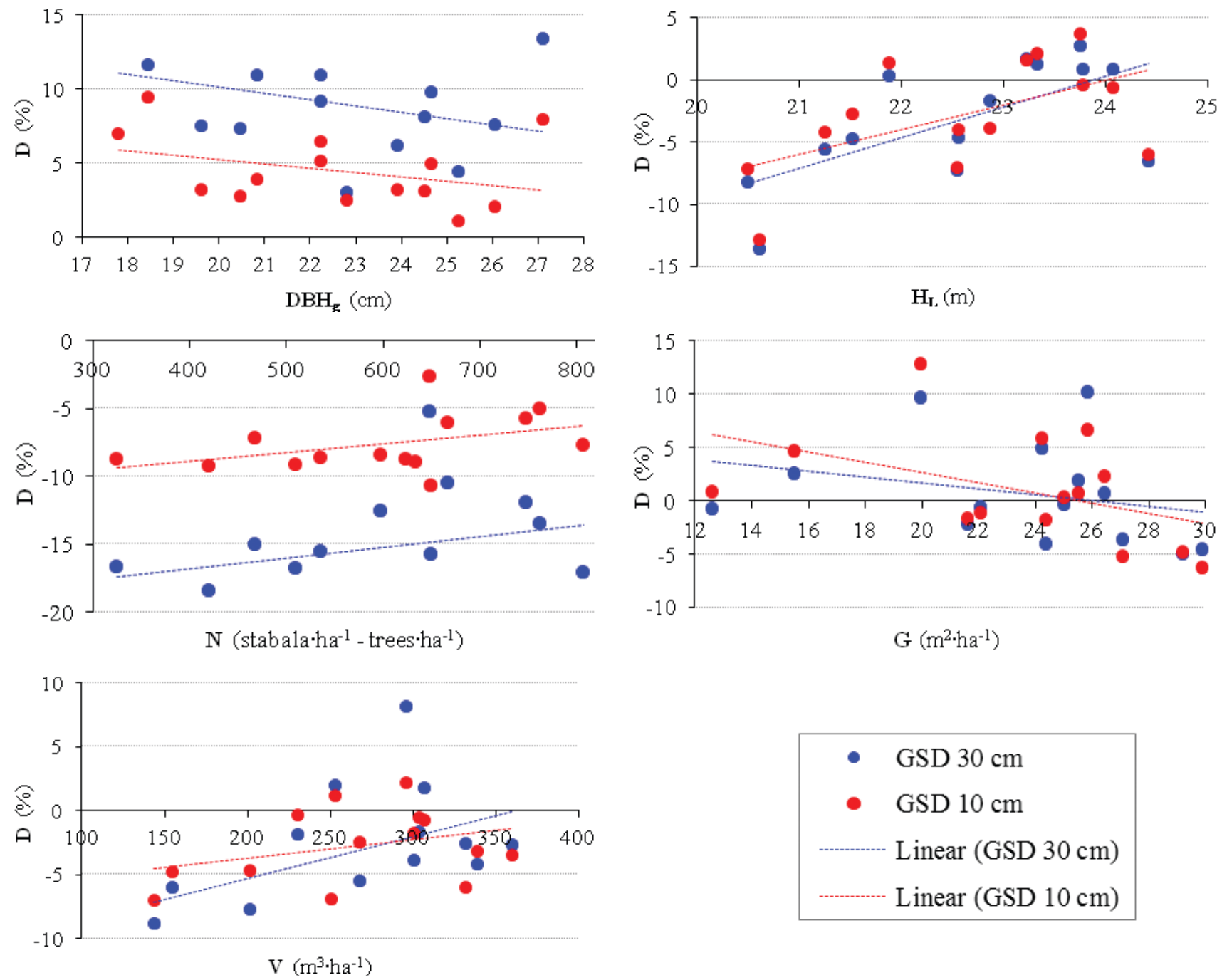

Slika 2. Odstupanja $\left(\mathrm{D}_{\%}\right)$ strukturnih elemenata sastojina $\left(\mathrm{DBH}_{\mathrm{q}}\right.$ - srednji sastojinski promjer, $\mathrm{H}_{\mathrm{L}}$ - Loreyeva srednja sastojinska visina, $\mathrm{N}-$ broj stabala, G - temeljnica, V - volumen) procijenjenih fotogrametrijskom izmjerom na aerosnimkama GSD 10 i GSD $30 \mathrm{~cm}$ u odnosu na referentne terenske vrijednosti.

Figure 2 Differences $\left(\mathrm{D}_{\%}\right)$ between photogrammetric $(G S D 30 \mathrm{~cm}$ and GSD $10 \mathrm{~cm})$ and field estimaes for basal-area weighted mean dbh $(\text { DBH })_{\mathrm{g}}$, Lorey's mean height $\left(H_{L}\right)$, stand density $(N)$, basal area $(G)$ and volume $(V)$ in relation to reference field estimates. 
procijenjena vrijednost promatrane varijable za odsjek $i$, a $\bar{F}_{i}$ je aritmečki srednja vrijednost terenski procijenjenih vrijednosti promatrane varijable.

MD ukazuje na predznak odstupanja fotogrametrijski procijenjenih vrijednosti, odnosno da li fotogrametrijski procijenjene varijable u prosjeku podcjenjuju ili precjenjuju terenske vrijednosti. Često se označava i kao pristranost (eng. bias), jer ukazuje sistemsku pogrešku procijenjenih vrijednosti. RMSE ukazuje na točnost fotogrametrijski procijenjenih vrijednosti u odnosu na referentne terenske vrijednosti.

\section{REZULTATI}

RESULTS

Rezultati odnosno odstupanja fotogrametrijski procijenjenih strukturnih elemenata sastojina $\left(\mathrm{DBH}_{\mathrm{g}}, \mathrm{H}_{\mathrm{L}}, \mathrm{N}, \mathrm{G}, \mathrm{V}\right) \mathrm{u}$ odnosu na terenski procijenjene prikazani su u tablici 3. Iz dobivenih rezultata vidljivo je da su fotogrametrijskom izmjerom na aerosnimkama GSD $30 \mathrm{~cm}$ i GSD $10 \mathrm{~cm}$ s najvećom točnošću procijenjeni $\mathrm{H}_{\mathrm{L}}, \mathrm{G}$ i V , pri čemu je raspon RMSE $_{\%}$ iznosio od 3,65\% do 5,36\%. Slična točnost dobivena je i za $\mathrm{DBH}_{\mathrm{g}}$ procijenjen na aerosnimkama GSD $10 \mathrm{~cm}$ $\left(\mathrm{RMSE}_{\%}=4,94 \%\right)$, dok je nešto slabija točnost dobivena za $\mathrm{N}$ procijenjen na aerosnimkama GSD $10 \mathrm{~cm}$ $\left(\mathrm{RMSE}_{\%}=7,71 \%\right)$, te $\mathrm{DBH}_{\mathrm{g}}$ procijenjen na aerosnimkama

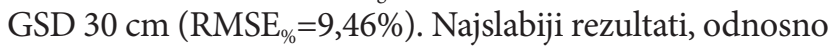
najmanja točnost dobivena je za N procijenjen na aerosnimkama GSD $30\left(\mathrm{RMSE}_{\%}=15,90 \%\right)$.

Iz prikazanih rezultata (tablica 3) vidljivo je da su fotogrametrijskom izmjerom na aerosnimkama GSD $30 \mathrm{~cm}$ i GSD
$10 \mathrm{~cm}$ dobivena podjednaka odstupanja za $\mathrm{H}_{\mathrm{L}}$ i G, u odnosu na terensku izmjeru, dok je $\mathrm{V}$ procijenjen s nešto većom točnošću na aerosnimkama GSD $10 \mathrm{~cm}$, nego na aerosnimkama GSD $30 \mathrm{~cm}$. Najveća razlika između rezultata dviju fotogrametrijskih izmjera dobivena su za $\mathrm{DBH}_{\mathrm{g}} \mathrm{i} \mathrm{N}$, gdje su na aerosnimkama GSD $30 \mathrm{~cm}$ pogreške procijene bile otprilike dvostruko veće nego na aerosnimkama GSD $10 \mathrm{~cm}$.

Nadalje, predznaci dobivenih srednjih odstupanja (MD, $\mathrm{MD}_{\%}$ ) za sve promatrane strukturne elemente sastojine bili su jednaki kod obje fotogrametrijske izmjere. Pozitivni predznaci srednjih odstupanja za $\mathrm{DBH}_{\mathrm{g}}$ i G ukazuju da su ti elementi u prosjeku precijenjeni fotogrametrijskom izmjerom, u odnosu na vrijednosti dobivene terenskom izmjerom. Analogno tomu, negativni predznaci srednjih odstupanja za $\mathrm{H}_{\mathrm{L}}, \mathrm{N}$ i $\mathrm{V}$ ukazuju na podcjenjivanje tih elemenata (u prosjeku) u odnosu na vrijednosti dobivene terenskom izmjerom.

Potvrda tome su i grafički prikazi (slika 2) odnosa postotnih odstupanja $\left(\mathrm{D}_{\%}\right)$ po odsjecima za sve promatrane varijable. Iz prikaza je vidljivo da fotogrametrijski procijenjeni $\mathrm{H}_{\mathrm{L}}$ i $\mathrm{V}$ u pojedinim odsjecima precjenjuju, a u pojedinim podcjenjuju terenski procijenjene vrijednosti, ali sveukupno imaju laganu (blagu) tendenciju podcjenjivanja. Također, fotogrametrijski procijenjena $\mathrm{G}$ također varira između precjenjivanja i podcjenjivanja, ali s laganom (blagom) tendencijom precjenjivanja terenskih procjena. Nadalje, s obje fotogrametrijske izmjere dobivene su precijenjene vrijednosti za $\mathrm{DBH}_{\mathrm{g}}$ i to u svim odsjecima. Fotogrametrijskom izmjerom na aerosnimkama GSD $10 \mathrm{~cm}$ dobiveno je precjenjivanje u rasponu od $1,1 \%$ do $9,5 \%$, dok je na aerosnimkama GSD $30 \mathrm{~cm}$ precjenjivanje iznosilo od $3,0 \%$ to $16,5 \%$. Na-

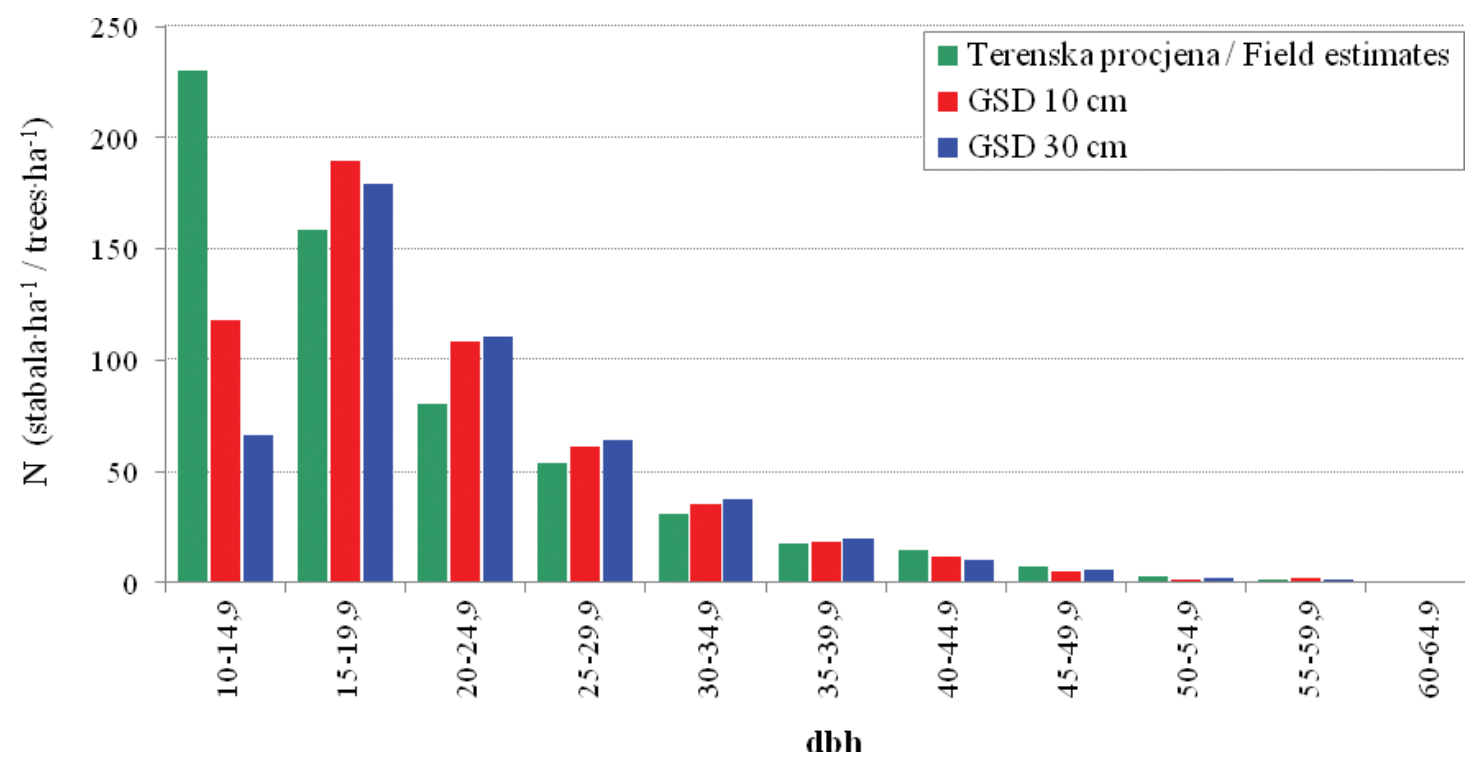

Slika 3. Distribucije broja stabala po debljinskim stupnjevima po hektaru procijenjene terenskom i fotogrametrijskim izmjerama na aerosnimkama GSD 30 i GSD $10 \mathrm{~cm}$ (Balenović i dr. 2013)

Figure 3 Overall DBH size class distributions (average number of trees per DBH size classes) of the whole study area estimated by field and photogrammetric measurements (GSD $30 \mathrm{~cm}$ and GSD $10 \mathrm{~cm}$ ) (Balenović et al. 2013) 
suprot tomu, kod obje fotogrametrijske izmjere vidljivo je konstantno podcjenjivanje broja stabala $(\mathrm{N})$, pri čemu su se podcjenjivanja dobivena izmjerom aerosnimaka GSD 10 cm kretala u rasponu od $-2,6 \%$ do $-10,6 \%$, a izmjerom aerosnimaka GSD $30 \mathrm{~cm}$ u rasponu $-5,1 \%$ do $-24,4 \%$.

Ukoliko se usporede distribucije broja stabala po debljinskim stupnjevima svih izmjera (slika 3), najveća odstupanja odnosno najveće podcjenjivanje broja stabala fotogrametrijskom izmjerom uočava se u najnižem debljinskom stupnju $(10,0-14,9 \mathrm{~cm})$. Već u sljedeća četiri debljinska stupnja (od 15,0-19,9 cm do 30,0-34,9 cm) dolazi do precjenjivanja fotogrametrijskog broja stabala, dok se u višim debljinskim stupnjevima brojevi stabala svih izmjera manje-više podudaraju.

\section{RASPRAVA I ZAKLJUČCI DISCUSSION AND CONCLUSIONS}

Kao što je djelomično već istaknuto u prethodnim istraživanjima (Balenović i dr. 2013, 2015a), podcjenjivanje broja stabala fotogrametrijskom izmjerom je gotovo neizbježno. Naime, do podcjenjivanja broja stabala fotogrametrijskom izmjerom najčešće dolazi zbog: (a) tzv. 'spojenih' krošanja, kada se dva ili više stabla interpretiraju kao jedno, (b) zasjenjenih stabala na aerosnimkama, pa se pojedina stabla ne uočavaju, te (c) nemogućnosti izmjere stabala podstojne etaže (Van Laar i Akça 2007). U slučaju vizualne (analogne) interpretacije aerosnimaka, na iznos podcjenjivanja broja stabala te općenito na uspjeh interpretacije i točnost procjene strukturnih elemenata sastojina utječe nekoliko faktora. To su: kvaliteta i karakteristike aerosnimaka (geometrijska, radiometrijska i spektralna rezolucija, odnos baze snimanja i visine leta), uvjeti aerosnimanja (kut položaja sunca i atmosferski uvjeti), karakteristike šumskih sastojina (starost, gustoća, omjer smjese vrste drveća, fenologija, itd.), stanišne karakteristike (nadmorska visina, reljefni oblik, nagib, ekspozicija) te sama metoda interpretacije (stereo oprema, vještina i iskustvo interpretatora (Magnuson i dr. 2007).

Utjecaj geometrijske odnosno prostorne rezolucije (GSD) aerosnimaka na podcjenjivanje broja stabala $(\mathrm{N})$ potvrđen je i u okviru ovog istraživanja. Naime, fotogrametrijskom izmjerom na aerosnimkama GSD $30 \mathrm{~cm}$ dobivena su gotovo dvostruko veća podcjenjivanja nego na aerosnimkama GSD $10 \mathrm{~cm}$. Glavni razlog tomu je slabija razlučivost detalja na snimkama nižih prostornih rezolucija, ponajprije ruba krošanja pojedinačnih stabala. Stoga se nerijetko dvije ili više 'spojenih' krošanja susjednih stabala interpretiraju kao krošnja jednog stabla, što posredno dovodi do podcjenjivanja broja stabala. Usporedbom distribucija broja stabala po debljinskom stupnjevima (slika 3) vidljivo je da značajno podcjenjivanje broja stabala kod obje fotogrametrijske izmjere je jedino u najnižem debljinskom stupnju (10,0-14,9 $\mathrm{cm}$ ), dok u sljedeća četiri debljinska stupnja (od 15,0-19,9 $\mathrm{cm}$ do $30,0-34,9 \mathrm{~cm}$ ) dolazi do precjenjivanja fotogrametrijskog broja stabala. Pretpostavka je da je upravo u najnižem debljinskom stupnju došlo do pogrešne interpretacije, pa su krošnje dva ili više manjih stabala interpretirane kao krošnja jednog većeg stabla, što je u konačnici rezultiralo "odljevom“ određenog broja stabala iz nižeg u viši debljinski stupanj. Također, podcjenjivanje je dijelom uzrokovano i nemogućnošću interpretacije zasjenjenih stabala te stabala iz podstojne etaže. Značajno podcjenjivanje fotogrametrijski procijenjenog broja stabala u odnosu na terenski uobičajeni je rezultat većine dosadašnjih istraživanja. Naesset (1996) je u sastojinama četinjača vizualnom interpretacijom analognih aerosnimaka podcjenjivao broj stabala u rasponu od -5 do $-47 \%$. Također vizualnom interpretacijom analognih aerosnimaka, Eid i dr. (2004) su u jednodobnim kulturama četinjača na dva područja istraživanja procjenjivali fotogrametrijski broj stabala s prosječnim (srednjim) odstupanjima od $-0,6 \%$ i $-4,4 \%$, dok su se odstupanja po sastojinama kretala u rasponu od -59 do $96 \%$.

Uslijed istog razloga ('spojene’ krošnje), fotogrametrijskom izmjerom dobivene su precijenjene vrijednosti srednjeg sastojinskog promjera $\left(\mathrm{DBH}_{\mathrm{g}}\right)$ i to u svim odsjecima. Naime, pojava spojenih krošanja dovela je do pogrešne izmjere, odnosno precjenjivanja promjera krošnje. Kako je fotogrametrijski prsni promjer svakom stablu na plohi izračunat na temelju izmjerene visine stabla i promjera krošnje, precijenjeni promjer krošnje uzrokovao je precjenjivanje izračunatog prsnog promjera, te u konačnici i precjenjivanje srednjeg sastojinskog promjera. Analogno kao i kod broja stabala, pogreške procijene srednjeg sastojinskog promjera bile su dvostruko veće na aerosnimkama GSD $30 \mathrm{~cm}$ nego na aerosnimkama GSD $10 \mathrm{~cm}$. Dobiveni rezultati (precjenjivanje srednjeg sastojinskog prsnog promjera) u skladu su s rezultatima većine dosadašnjih istraživanja, bilo da se radi o analognoj (Tomašegović 1986) ili automatskoj interpretaciji aerosnimaka (Zagalikis i dr. 2005).

Nasuprot broju stabala i srednjem sastojinskom promjeru, srednja sastojinska visina $\left(\mathrm{H}_{\mathrm{L}}\right)$ procijenjena je s gotovo jednakom točnošću na aerosnimkama GSD $10 \mathrm{~cm}$ i GSD 30 $\mathrm{cm}$, pri čemu su u oba slučaja dobivena relativno mala odstupanja u odnosu na terensku procjenu. Dakle, fotogrametrijskom izmjerom podcijenjeni broj stabala nije utjecao na točnost izmjere srednje sastojinske visine. Stoga se može pretpostaviti da su uzrok podcjenjivanja stabala u najvećoj mjeri tzv. 'spojene' krošnje, a u manjoj mjeri zasjenjena stabla i stabla podstojne etaže. To je i razumljivo, budući da su predmetne raznodobne sastojine sačinjene od niza manjih jednodobnih sastojina s manjim udjelom stabala podstojne etaže. Naime, u slučaju većeg udjela stabala podstojne etaže, koja ne bi bilo moguće interpretirati na aerosnimkama, fotogrametrijski procijenjena srednja sastojinska visina značajnije bi odstupala od terenski procijenjene. Usporede li se 
dobiveni rezultati s rezultatima dosadašnjih istraživanja provedenim vizualnom interpretacijom na analognim (Ståhl 1992, Benko 1993, Næsset 1996, Kovats 1997, Anttila 1998, Eid i dr. 2004, Magnusson i Fransson 2005) ili digitalnim aerosnimkama (Magnusson i dr. 2007), razvidno je kako u ovom radu primijenjena metoda fotogrametrijske izmjere visina na digitalnim aerosnimkama visokih prostornih rezolucija (GSD $10 \mathrm{~cm}$ i GSD $30 \mathrm{~cm}$ ) daje rezultate poboljšane točnosti, odnosno manja odstupanja od terenski izmjerenih podataka. U već spomenutom istraživanju, Eid i dr. (2004) navode prosječna odstupanja fotogrametrijskih visina dominantnih stabala za cijelo područje istraživanja od -5,6 i -5,5\%, dok su se odstupanja fotogrametrijskih visina pojedinačnih sastojina kretala u rasponu od -29 do $26 \%$ u odnosu na terenski procijenjene visine. Magnusson i dr. (2007) procjenjivali su srednje sastojinske visine manualnom interpretacijom Z/I DMC digitalnih aerosnimaka GSD $48 \mathrm{~cm}$ s odstupanjima (RMSE) od 0,9 do 1,6 m u odnosu na terensku izmjeru. Nadalje, Korpela (2004) je istaknuo da problem podcjenjivanja visina stabala prilikom vizualne interpretacije proizlazi zbog nemogućnosti točnog određivanja vrha stabla na analognim (ili digitalnim) aerosnimkama niskih prostornih rezolucija, te nemogućnosti očitanja tla (pokraj stabla) uslijed sklopljenosti krošanja. Primjenom u ovom radu korištene metode, ponajprije DMR-a, koji omogućuje očitanje nadmorske visine tla (podnožja stabla) u gustim sklopljenim sastojinama i digitalnih aerosnimaka visokih prostornih rezolucija, koje omogućuju jasno određivanje vrha stabla, ne dolazi do uobičajenog podcjenjivanja visine stabala.

Nadalje, unatoč podcjenjivanju broja stabala i precjenjivanju srednjeg sastojinskog promjera, obje fotogrametrijske izmjere polučile su vrlo dobre rezultate odnosno razmjerno mala odstupanja pri procjeni temeljnice i volumena sastojina. Usporedbe radi, Kušan (1992) je procjenjivao temeljnice sastojina jele i smreke kombinacijom fotogrametrijske izmjere analognih aerosnimaka i prirasno-prihodnih tablica. Primjenom Hauserovih prirasno-prihodnih tablica dobio je prosječna odstupanja od $13,9 \%$, a primjenom Švicarskih tablica odstupanja od -16,5\% u odnosu na terenski procijenjenu temeljnicu. Slična odstupanja (standardna pogreška), u rasponu od $-12,7$ do $22,8 \%$ dobivena su u nizu istraživanja provedenih u sastojinama četinjača u Skandinaviji (Eid 2003, Naesset 1996). Eid i dr. (2004) dobivaju znatno manja prosječna odstupanja: $-7,1 \%$ za jedno, te $-5,4$ $\%$ za drugo područje istraživanja. Međutim, kao i pri procjeni broja stabala, dobivaju velika odstupanja pojedinačnih sastojina, i to u rasponu od -37 do $51 \%$. U okviru brojnih istraživanja provedenih vizualnom interpretacijom analognih aerosnimaka volumen sastojina procjenjivan je sa standardnom pogreškom u rasponu od 13-33\% (Ericson 1984, Ståhl 1992, Eid 1996, Næsset 1996, Eid i Næsset 1998, Magnusson i Fransson 2005), dok su Magnusson i dr. (2007) procijenjivali volumen sastojina na digitalnim aerosnimkama GSD $48 \mathrm{~cm}$ uz prosječni RMSE od $24 \%$.

Izravna usporedba s rezultatima prijašnjih istraživanja nije moguća, budući da su tijekom istih korištene aerosnimke različitih karakteristika (većinom analogne ili u manjoj mjeri digitalne, slabijih prostornih rezolucija). Nadalje, istraživanja su provedena u sastojinama drukčijih strukturnih karakteristika, i to većinom u jednodobnim sastojinama ili kulturama četinjača (Skandinavske zemlje). Pri tome, za procjenu točnosti fotogrametrijske izmjere korištene su različite mjere odstupanja (npr. standardna pogreška), te su fotogrametrijski podaci uspoređivani s terenskima na različitim razinama (uglavnom na razini primjernih ploha). Međutim, unatoč nemogućnosti izravne usporedbe, razvidno je da su u okviru ovog istraživanja dobivena manja odstupanja fotogrametrijski procijenjenih strukturnih elemenata sastojina u odnosu na terenski procijenjene, $i$ to posebice na aerosnimkama GSD $10 \mathrm{~cm}$. Primjena digitalnih aerosnimaka poboljšane kvalitete (prostorne, radiometrijske, spektralne rezolucije) dovela je do smanjenja odstupanja pri fotogrametrijskoj procjeni visina, prsnog promjera i broja stabala, što je u konačnici dovelo do povećanja točnosti procjene prosječne temeljnice i volumena sastojina. Dakle, pogreške precjenjivanja prsnih promjera i podcjenjivanja broja stabala djelomično se poništavaju, što dovodi do točne ili približno točne procjene temeljnice i volumena. Budući da kod obje fotogrametrijske izmjere dobivamo slična odstupanja, evidentno je da kod fotogrametrijske izmjere na aerosnimkama GSD $30 \mathrm{~cm}$ precjenjivanje prsnih promjera i podcjenjivanje broja stabala je toliko veće, da u konačnici ipak dobijemo procjene temeljnica i volumena kao i kod fotogrametrijske izmjere na aerosnimkama GSD $10 \mathrm{~cm}$. Također, na točnost dobivenih podataka zasigurno utječe i primjena lokalnih regresijskih modela procjene prsnog promjera koji su izrađeni za glavne vrste drveća na području istraživanja.

Što se tiče mogućnosti determinacije odnosno vizualne interpretacije vrsta drveća na digitalnim aerosnimkama, tijekom istraživanja je prema očekivanjima utvrđeno da aerosnimke GSD $10 \mathrm{~cm}$ pružaju znatno veću mogućnost razlučivanja detalja, pa prema tome i lakšu determinaciju pojedinih vrsta drveća u odnosu na aerosnimke GSD 30 $\mathrm{cm}$. Nakon provedene fotogrametrijske izmjere može se zaključiti da se vizualnom interpretacijom u stereomodelu na digitalnim aerosnimkama GSD $30 \mathrm{~cm}$ pouzdano mogu determinirati (razlučiti) srednjodobna i starija stabla hrasta kitnjaka, obične bukve, zatim crne johe neovisno o starosti, te vrste drveća iz skupine OMB (topole, breze), zbog njihovog specifičnog preslikavanja na ICK aerosnimkama. Međutim, teškoće nastaju u mladim mješovitim sastojinama, gdje je prilično teško razlikovati stabla obične bukve, graba i ostalih vrsta drveća. U takvim situacijama, važno je iskustvo samog interpretatora, ali i poznavanje barem približne 
strukture sastojine s obzirom na sastav vrsta drveća odnosno mogućnost pojave pojedinih vrsta drveća na određenom dijelu terena. Iz navedenih razloga potrebni su određeni obilasci terena prije same fotogrametrijske izmjere, koji su u ovom slučaju odrađeni tijekom terenske izmjere strukturnih elemenata sastojina u svrhu izrade regresijskih modela procijene prsnih promjera.

Naposljetku, slijedom navedenog razvidno je kako su rezultati provedenog istraživanja potvrdili velik potencijal primjene digitalnih stereo aerosnimaka visokih prostornih rezolucija u inventuri šuma. Usporedbom rezultata fotogrametrijske izmjere na digitalnim aerosnimkama GSD $30 \mathrm{~cm}$ i GSD $10 \mathrm{~cm}$ s rezultatima terenske izmjere utvrđeno je da aerosnimke GSD $30 \mathrm{~cm}$ pružaju mogućnost procjene srednjih sastojinskih visina, sastojinske temeljnice i volumena s gotovo jednakom točnošću kao i aerosnimke GSD $10 \mathrm{~cm}$. Međutim, pogreške procijene srednjeg sastojinskog promjera i broja stabala bile su gotovo dvostruko veće na aerosnimkama GSD $30 \mathrm{~cm}$, nego na aerosnimkama GSD $10 \mathrm{~cm}$. Stoga se može zaključiti, kako aerosnimke GSD 10 $\mathrm{cm}$ sveukupno daju bolje rezultate procjene strukturnih elemenata sastojina, jer prikazuje strukturu sastojine bliže stvarnoj. Međutim, potencijalnom korisniku ostaje na izbor rezolucija aerosnimaka s obzirom na vrstu podataka i željenu točnost koju želi dobiti iz aerosnimaka.

\section{LITERATURA}

\section{REFERENCES}

- Anttila, P., 1998: On the accuracy of treewise attributes obtained by analytical stereoplotter and aerial images. Magisterij, 36 str., Faculty of Forestry, University of Joensuu.

- Balenović, I., H. Marjanović, M. Benko, 2010: Primjena aerosnimaka u uređivanju šuma u Hrvatskoj. Šum. list, 134 (11-12): 623-631.

- Balenović, I., A. Seletković, R. Pernar, H. Marjanović, D. Vuletić, M. Benko, 2012: Comparison of Classical Terrestrial and Photogrammetric Method in Creating Management Division. U: T. Pentek, T. Poršinsky, M. Šporčić (ur.) Proceedings of 45th International Symposium on Forestry Mechanization: 'Forest Engineering - Concern, Knowledge and Accountability in Today's Environment", Šumarski fakultet Sveučilišta u Zagrebu, 1-13, Zagreb.

- Balenović, I., H. Marjanović, K. Indir, D. Vuletić, M.Z. Ostrogović, M. Benko, 2013: Estimation of the Stands' Arithmetic Mean Diameter using Manual Method of Digital Photogrammetry. Period. Biol., 115 (3): 399-407.

- Balenović, I., A. Seletković, R. Pernar, A. Jazbec, 2015a: Estimation of the mean tree height of forest stands by photogrammetric measurement using digital aerial images of high spatial resolution. Ann. For. Res., 58 (1): 125-143.

- Balenović, I., H. Marjanović, D. Vuletić, E. Paladinić, M.Z. Ostrogović Sever, K. Indir, 2015b: Quality assessment of high density digital surface model over different land cover classes. Period. Biol., 117 (4): 459-470.
- Benko, M., 1993: Procjena taksacijskih elemenata sastojina na infracrvenim kolornim aerosnimkama. Glas. šum. pokuse, 29: 199-274.

- Bezak, K, 2001: Parametri Špirančevih drvnogromadnih tablica za krupno drvo hrasta lužnjaka (Quercus robur L.), hrasta kitnjaka (Quercus petrea L.) i bukvu (Fagus sylvatica L.). Šum. list 125 (11-12): 635-640.

- Cestar, D., Đ. Kovačić, 1981: Tablice drvnih masa domaćih i euroameričkih topola. Radovi - Šumar. inst. Jastrebar., 42: 1-176.

- Cestar, D., Đ. Kovačić, 1982: Drvnogromadne tablice za crnu johu i bagrem. Radovi - Šumar. inst. Jastrebar., 49: 1-149.

- Eid, T., 1996.: Kontroll av skogbruksplandata fra "Understøttet fototakst". Dept of Forest Sciences, Agric. Univ. of Norway, As, Aktuelt fra Skogforsk 8-1996, 21.

- Eid, T., 2003: Kontroll av relaskoptakster og fototakster (Registreringer i Aas skog 1960-2000). U: Aktuelt fra skogforskningen $5,10-17$.

- Eid, T., E. Næsset, 1998: Determination of stand volume in practical forest inventories based on field measurements and photointerpretation: The Norwegian experience. Scand. J. For. Res.,13 (2): 246-254.

- Eid, T., T. Gobakken, E. Næsset, 2004: Comparing stand inventories for large areas based on photo-interpretation and laser scanning by means of cost-plus-loss analyses. Scand. J. For. Res., 19 (6): 512-523.

- Erikson, O., 1984: Stand inventory by aerial photogrammetry. The Forest Operations Institute of Sweden. Forskningsstiftelsen Skogsarbeten. Redogörelse 8. 19 str.

- Ginzler, C., M.L. Hobi, 2015: Countrywide Stereo-Image Matching for Updating Digital Surface Models in the Framework of the Swiss National Forest Inventory. Remote Sens., 2015, 7 (4): 4343-4370.

- Gong, P., Y. Sheng, G.S. Blging, 2002: 3D Model-Based Tree Measurement from High-Resolution Aerial Imagery. Photogramm. Eng. Rem. S., 68 (11): 1203-1212.

- Gruber M., M. Ponticellia, S. Bernögger, F. Leberl, 2008: Ultracamx, the Large Format Digital Aerial Camera System by Vexcel Imaging/Microsoft. U: Proceedings of ISPRS XXIst Congress 'Silk Road for Information from Imagery', Vol. XXXVII, Part B1, 665-670, Beijing.

- Kolić, J., R. Pernar, A. Seletković, M. Ančić, 2015: The Importance of CIR Aerial Imagery in Inventory, Monitoring and Predicting Forest Condition. South-east Eur. for., 6 (2): 191-200.

- Korpela, I., 2004: Individual tree measurements by means of digital aerial photogrammetry. Silva Fenn. monogr., 3: 1-93.

- Kovats, M., 1997: A large-scale aerial photographic technique for measuring tree heights on long-term forest installations. Photogramm. Eng. Rem. S., 63 (6): 741-747.

- Kušan, V., 1992: Procjena volumena sastojina četinjača fotointerpretacijom aerosnimaka uz pomoć prirasno-prihodnih tablica. Meh. šumar., 17 (3-4): 53-66.

- Kušan, V., 1996: Pristup daljinskim istraživanjima i GIS-u u hrvatskome šumarstvu. Šum. list, 120 (3-4): 171-178.

- Linder, W., 2009: Digital photoogrammetry - A practical course. Springer, 220 str., Berlin.

- Magnusson, M., J.E.S. Fransson, 2005: Evaluation of aerial photo-interpretation for estimation of forest stem volume at stand level. U: H. Olsson (ur.), Proceedings of the EARSeL, IUFRO, ISPRS Workshop ForestSAT 2005, Operational Tools in Forestry Using Remote Sensing Techniques, Swedish Forest Agency, Report 8, Volume C, 102-106, Borås, Sweden. 
- Magnusson, M., J.E.S. Fransson, H. Olsson, 2007: Aerial photointerpretation using Z/I DMC images for estimation of forest variables. Scand. J. Forest Res., 22 (3): 254-266.

- Michailoff, I., 1943: Zahlenmässiges Verfahren für die Ausführung der Bestandeshöhenkurven. Cbl. und Thar. Forstl. Jahrbuch 6: 273-279.

- Næsset, E., 1996: Determination of number of stems in coniferous forest stands by means of aerial photo-interpretation. Scand. J. For. Res., 11 (1): 76-84.

- Næsset, E., 2002: Determination of mean tree height of forest stands by means of digital photogrammetry. Scand. J. Forest Res., 17 (5): 446-459.

- NN, 2006: Pravilnik o uređivanju šuma. Narodne novine, 111, Zagreb.

- NN, 2008: Pravilnik o izmjenama i dopunama Pravilnika o uređivanju šuma. Narodne novine, 141, Zagreb.

- Ota, T., M. Ogawa, K. Shimizu, T. Kajisa, N. Mizoue, S. Yoshida, G. Takao, Y. Hirata, N. Furuya, T. Sano, H. Sokh, V. Ma, E. Ito, J. Toriyama, Y. Monda, H. Saito, Y. Kiyono, S. Chann, N. Ket, 2015: Aboveground Biomass Estimation Using Structure from Motion Approach with Aerial Photographs in a Seasonal Tropical Forest. Forests, 6 (11): 3882-3898.

- Pernar, R., 1994: Način i pouzdanost određivanja oštećenosti hrasta lužnjaka (Quercus robur L.) na infracrvenim kolornim (ICK) aerosnimkama. Glas. šum. pokuse, 31: 1-34.

- Pernar, R., 1997: Application of results of aerial photograph interpretation and geographical information system for planning in forestry. Glas. šum. pokuse, 34: 141-149.

- Pernar, R., A. Seletković, M. Ančić, 2007a: Utvrđivanje oštećenosti šuma Spačvanskog bazena primjenom infracrvenih kolornih aerosnimaka. Šum. list, 131 (7-8): 315-322.

- Pernar, R., M. Ančić, A. Seletković, 2007b: Primjena ICK aerosnimaka za utvrđivanje oštećenosti šuma na području UŠP Gospić. Šum. list, 131 (11-12): 507-521.

- Pernar, R., A. Seletković, M. Ančić, M. Vedriš, K. Teslak, 2008: Assessing the health status of beech-fir forests using remote sensing methods. Period. Biol., 110 (2): 157-161.

- Petrie G., A. S. Walker, 2007: Airborne Digital Imaging Technology: a New Overview. Photogramm. Rec., 22 (119): 203-225.

- Sandau, R., 2010: Digital Airborne Camera, Introduction and Technology. Springer, 343 str., Dordrecht.
- Schumacher, F.X., F.D.S. Hall, 1933: Logarithhmic expression of timber-tree volume. J. Agr. Res., 47: 719-734.

- Seletković, A., M. Perić, I. Balenović, 2016: Fotogrametrijska procjena srednjih sastojinskih visina odvojeno po vrstama drveća u mješovitim sastojinama središnje Hrvatske. Nova meh. šumar., 37: 15-23.

- Smits, I., G. Prieditis, S. Dagis, D. Dubrovskis, 2012: Individual tree identification using different LIDAR and optical imagery dana processing methods. Biosystems and Information Technology, 1 (1): 19-24.

- Ståhl, G., 1992: A study on the quality of compartmentwise forest data acquired by subjective inventory methods (Report 24). Umeå: Department of Biometry and Forest Management, Swedish University of Agricultural Sciences.

- Špiranec, M., 1975: Drvnogromadne tablice. Radovi - Šumar. inst. Jastrebar., 22: 1-262.

- Tomašegović, Z., 1986: Fotogrametrija i fotointerpretacija u šumarstvu. Šumarski fakultet Sveučilišta u Zagrebu, 157 str., Zagreb.

- Tuominen, S., J. Pitkänen, A. Balazs, K.T. Korhonen, P. Hyvönen, E. Muinonen, 2014: NFI plots as complementary reference data in forest inventory based on airborne laser scanning and aerial photography in Finland. Silva Fenn., 48 (2): article id 983.

- Van Laar, A., A. Akça, 2007: Forest mensuration. Springer, 376 str., Dordrecht.

- White, J.C., C. Stepper, P. Tompalski, N.C. Coops, M.A. Wulder, 2015: Comparing ALS and Image-Based Point Cloud Metrics and Modelled Forest Inventory Attributes in a Complex Coastal Forest Environment. Forests, 6 (10): 3704-3732.

- Yu, X., J. Hyyppä, M. Karjalainen, K. Nurminen, K. Karila, M. Vastaranta, V. Kankare, H. Kaartinen, M. Holopainen, E. Honkavaara, A. Kukko, A.Jaakkola, X. Liang, Y. Wang, H. Hyyppä, M. Katoh, 2015: Comparison of Laser and Stereo Optical, SAR and InSAR Point Clouds from Air- and Space-Borne Sources in the Retrieval of Forest Inventory Attributes. Remote Sens., 7 (12): 15933-15954.

- Zagalikis, G., A.D. Cameron, D.R. Miller, 2005: The application of digital Photogrammetry and image analysis techniques to derive tree and stand characteristics. Can. J. Forest Res., 35 (5): 1224-1237.

\section{Summary}

Although the application of aerial stereo photogrammetry in forest inventory has a long tradition, in many countries including Croatia forest inventories are based on labour and time consuming field surveys. Therefore, the objective of this research was to evaluate the applicability of using the digital aerial images of high spatial resolution (ground sampling distance-GSD of $10 \mathrm{~cm}$ and $30 \mathrm{~cm}$ ) for predicting forest stand attributes (basal-area weighted mean dbh $-\mathrm{DBH}_{\mathrm{g}}$, Lorey's mean height $-\mathrm{H}_{\mathrm{L}}$, stand density $-\mathrm{N}$, basal area $-\mathrm{G}$, volume - V). This research continues the work of the previous research (Balenović et al. 2013, 2015a), where accuracy of photogrammetrically estimated arithmetic mean diameter and arithmetic mean height of forest stands were evaluated.

The research was conducted in the even-aged (sessile oak management class) and the multi-aged stands (European beech and common hornbeam management classes) of a privately owned forest in the management unit Donja Kupčina - Pisarovina, $25 \mathrm{~km}$ south of Zagreb, Croatia (Figure 1). Field data were collected during the spring and summer of 2009 as part of the regular forest inventory conducted according to the valid Regulation on Forest Management. A total of 183 circular plots with radii of 8 or 12 m were systematically set in 
the 14 selected subcompartments. The positions of the sample plot centres were recorded with GPS receiver. Within each plot, the diameter at breast height $(\mathrm{dbh})$ was measured and tree species was determined for all trees with $\mathrm{dbh} \geq 10 \mathrm{~cm}$. The height of each tree was calculated by means of the constructed local height curves fitted with Michailloff's function. The basal area (g) of each tree was calculated from the measured dbhs using standard equation, whereas the merchantable tree volume up to a diameter of $7 \mathrm{~cm}$ overbark (v) was calculated from field-measured dbh and estimated h using the Schumacher-Hall function and parameters from Croatian volume tables. The forest stand attributes were calculated by averaging data of all sampled tree within each stand $\left(\mathrm{DBH}_{\mathrm{g}}, \mathrm{H}_{\mathrm{L}}\right)$ or summing the tree data and dividing it by the total area of all plots for each stand $(\mathrm{N}, \mathrm{G}, \mathrm{V})$. Stand-level field data were used in the statistical analysis and comparison with photogrammetric data as a ground-truth reference data (Table 1).

The colour infrared (CIR) digital aerial images of GSD $30 \mathrm{~cm}$ and GSD $10 \mathrm{~cm}$ were acquired using a Microsoft UltraCamX digital large-format aerial camera during two aerial surveys in July 2009 (Figure 1, Table 2). The digital terrain data (breaklines, formlines, spot heights and mass points) for the digital terrain model (DTM) generation were collected by stereo-mapping of digital aerial images according to the rules of the Croatian State Geodetic Administration. The whole procedure of image acquisition, aerial triangulation, and collection of 3D data was conducted by Geofoto Ltd. (Zagreb, Croatia).

The photogrammetric stereo measurements and the visual interpretation of tree attributes were performed on digital aerial images of $30 \mathrm{~cm}$ GSD and $10 \mathrm{~cm}$ GSD using PHOTOMOD 5.24 digital photogrammetric system according to procedures described in Balenović et al. 2013, 2015a. The photogrammetric plots were overlaid upon the aerial images based on the spatial coordinates $(\mathrm{x}, \mathrm{y})$ of the field plot centres recorded by the GPS receiver. The determination of tree species and crown tops as well as the delineation of crown areas was performed manually for each tree whose top fell inside the plot. The height of each tree was calculated as the difference between the tree top elevations and the corresponding tree bottom elevations determined from the DTM. A raster DTM of $1 \mathrm{~m}$ grid size was generated through linear interpolation of a triangular irregular network (TIN) which was previously created from the digital terrain data. The dbh of each tree on the plot was calculated using local regression models with tree height and crown diameter as inputs (Balenović et al. 2012). Crown diameter was calculated from delineated crown area by applying the equation for circle surface area. Further calculations of photogrammetric tree $(g, v)$ and stand variables $\left(\mathrm{DBH}_{\mathrm{g}}, \mathrm{H}_{\mathrm{L}}, \mathrm{N}, \mathrm{G}, \mathrm{V}\right)$ were identical to previously described calculations of field data.

The accuracy of the photogrammetrically estimated stand attributes was evaluated by calculating differences (D), mean differences (MD) and RMSE between photogrammetric- and field-estimates. The relative values of $\mathrm{D}_{\%}, \mathrm{MD}_{\%}, \mathrm{RMSE}_{\%}$ were calculated according to the mean of the field reference values. The $\mathrm{D}$ and $\mathrm{D}_{\%}$ were calculated for each subcompartment, whereas $\mathrm{MD}, \mathrm{MD}_{\%}, \mathrm{RMSE}$ and $\mathrm{RMSE}_{\%}$ were calculated for the whole study area.

The results in Table 3 show that photogrammetric measurements of the aerial images of $30 \mathrm{~cm}$ GSD (PM30) and $10 \mathrm{~cm}$ GSD (PM10) produced reasonable accurate estimates for $\mathrm{H}_{\mathrm{L}}, \mathrm{G}, \mathrm{V}$ with relative RMSEs ranging from $3.65 \%$ to $5.36 \%$. Similar accuracy was obtained for $\mathrm{DBH}_{\mathrm{g}}$ estimated by PM10 (RMSE=4.94\%), while lower accuracy was obtained for $\mathrm{N}$ estimated by PM10 (RMSE=7.71\%) and $\mathrm{DBH}_{\mathrm{g}}$ estimated by PM30 (RMSE=9.460\%). The lowest accuracy was obtained for N estimated by PM30 (RMSE=15.90\%). Both photogrammetric measurements (PM10 and PM30) estimated $\mathrm{H}_{\mathrm{L}}$ and $\mathrm{G}$ with similar level of accuracy, whereas V was estimated with slightly higher accuracy by PM10 then by PM30. For estimation of DBHg and V, PM10 produced considerably better results, i.e. estimates of approximately twice higher accuracy then PM30. Figure 2 shows relations between $\mathrm{D}_{\%}$ and field estimates of corresponding attributes for each subcompartment. As can be seen, photogrammetrically estimated $\mathrm{H}_{\mathrm{L}}$ and $\mathrm{V}$ varied between overestimation and underestimation $\left(\mathrm{H}_{\mathrm{L}}\right.$ : from $-13.6 \%$ to $2.8 \%$ for PM10, from $-12.8 \%$ to $3.7 \%$ for PM30; V: from $-7.0 \%$ to $2.2 \%$ for PM10, from $-10.2 \%$ to $8.2 \%$ for PM30), but with a slight tendency to underestimate field estimates. Photogrammetrically estimated G also varied between overestimation and underestimation (from $-6.2 \%$ to $12.9 \%$ for PM10, from $-5.0 \%$ to $10.2 \%$ for PM30), but with a slight tendency to overestimate field estimates. DBHg was overestimated for all subcompartments by both photogrammetric measurements (from 1.1 to $9.5 \%$ for PM10; from 3.0\% to 16.5\% for PM30). On the contrary, both photogrammetric measurements underestimated $\mathrm{N}$ throughout all subcompartments (from $-2.6 \%$ to $-10.6 \%$ for PM10; from $-5.1 \%$ to $-24.4 \%$ for PM30). For both DBHg and N, PM30 produced estimates of lower accuracy than PM10. This is a consequence of lesser visibility of details (e.g. crown boundaries) on images of lower spatial resolution (GSD $30 \mathrm{~cm}$ ) and decreased ability to detect individual trees, especially in the part of stands with greater proportion of younger trees. According to Figure 3, the notable underestimation of $\mathrm{N}$ by PM30 was found in the lowest dbh size class $(10.0-14.9 \mathrm{~cm})$.

The results of this research showed that $\mathrm{H}_{\mathrm{L}}, \mathrm{G}$ and $\mathrm{V}$ can be accurately estimated by manual measurements of digital aerial images of high spatial resolution. The use of images of high spatial resolution, along with the 
use of local dbh models, led to improved accuracy regarding individual tree detection and dbh estimation. Moreover, the errors of $\mathrm{N}$ underestimation and $\mathrm{DBH}$ overestimation have been mutually abolished, which in the end resulted with reasonably accurate estimates of $\mathrm{G}$ and $\mathrm{V}$ at stand level. Since the errors of $\mathrm{N}$ underestimation and DBH overestimation with PM30 were both proportionally (twice) greater than with PM10, G and $\mathrm{V}$ were estimated on both $10 \mathrm{~cm}$ and $30 \mathrm{~cm}$ GSD images with similar level of accuracy. Although PM10 overall produced the more accurate results than PM30, it should be noted that the price of $10 \mathrm{~cm}$ images is several time higher than of $30 \mathrm{~cm}$ images. Therefore, a potential user should decide which images to use depending on desired accuracy and available funds.

KEY WORDS: forest inventory, stereo measurement, visual interpretation, digital aerial images, digital photogrammetric workstation 